\title{
Taxonomic Study on the Feather Stars (Crinoidea: Echinodermata) from Egyptian Red Sea Coasts and Suez Canal, Egypt
}

\author{
Ahmed M. Hellal \\ Marine Biology and Fish Science Section, Zoology Department, \\ Faculty of Science, Al-Azhar University, Cairo, Egypt \\ Email: Funyahem@Yahoo.com
}

Received November 27, 2011; revised January 16, 2012; accepted January 25, 2012

\begin{abstract}
A taxonomic study on the crinoids (feather stars) collected from 34 sites from the Red Sea coasts and islands as well as the Suez Canal was done during the period from 1992 to 2003. A total of 15 species are now known from the Red Sea belonging to eleven genera under six families. Among them four species are endemic to the Red Sea and the two species, Decametra chadwicki and Lamprometra klunzingeri, are recorded from the Suez Canal for the first time. Also, the two species, Oligometra serripinna and Dorometra aegyptica, are new record from Gulf of Suez, and Decametra mollis from Gulf of Aqaba and Northern Red Sea. This study represents the first proper documentation of crinoid species in the study area. Summaries are provided of the specific habitats and geographical distribution.
\end{abstract}

Keywords: Crinoidea; Red Sea; Suez Canal; Taxonomy; Habitats; Geographical Distribution

\section{Introduction}

Feather-stars constitute group of echinoderms belonging to class Crinoidea and order Comatulida, having five to hundreds of arms surrounding their cup-like bodies [1,2]. Just like their closest relatives, the sea lilies, feather stars are stalked only in the juvenile stage but detach their cup-like bodies in the adult stage to become freely moving or motile crinoids [2]. Feather stars are regarded as primitive echinoderms and today's living species all belong to the subclass Articulata [3]. Order Comatulida is composed of 18 extant families, with family Comasteridae being the most common in tropical shallow-water in both the Indo-West Pacific and the Western Atlantic [47]. Feather stars are among the least known echinoderms attributable to difficulty in their collection on account of their fragile nature, secretive habits, and distribution in deep waters. Also, their identification requires patience and painstaking attention to morphological details $[8,9]$. In the Red Sea, although it is believed that shallow waters ( $<50 \mathrm{~m}$ deep) are inhabited by living species of feather stars $[10,11]$, there are no documented studies to warrant this claim. In present study, identified key of all crinoid species known from the Red Sea was applied. Also summaries of the specific habitats and geographical distribution are provided.

\section{Material and Methods}

\subsection{Field Observation, Collection and Preservation}

Many field trips were made to the Egyptian Red Sea coasts and islands, Gulfs of Aqaba and Suez and Suez Canal lakes during the period from 1992 to 2003. A total of 34 sites were surveyed and intensive collections of feather stars were done. The survey included both tidal and subtidal habitats (e.g. coral reefs and rocky habitats). At each site, characteristics of specific habitats, position and site name, community structure, substrate type and crinoid distribution were recorded (Table 1). To loosen the animal's grip on the substrate, a small metal bar was inserted between the cirri and the substrate, a technique employed to avoid possible breakage to the fragile arms. The animals were then placed in containers filled with sea-water and transported back to land, the natural color was noted. The specimens were then carefully lifted and immersed into their respective sea-water-filled containers to which 95\% ethanol (3 parts sea water: 1 part 95\% ethanol) was added, oral side down with arms spread out. Using the fingers, pressure was gently applied for about 30 second to restrain and keep the specimen in place and hasten fixation. When the animal became totally immobile, the seawater-95\% ethanol solution was replaced 
Table 1. List of surveyed stations and habitat types along the coasts of the Red Sea, Gulf of Aqaba and Gulf of Suez during the period of study (1992-2003).

\begin{tabular}{|c|c|c|c|c|}
\hline \multirow{2}{*}{ No. } & \multirow{2}{*}{ Site name } & \multicolumn{3}{|c|}{ Site description } \\
\hline & & Latitude & Longitude & Habitat types \\
\hline 1 & Ras Abu-Galum & 28.3750 & 34.3550 & Coral, Rubble/Cobble, Sand \\
\hline 2 & Sharm El-Sheik & 27.5070 & 34.1625 & Live coral, Rock, Gravel, Sand \\
\hline 3 & Ain Sukhna I & 29.3334 & 32.2169 & Live coral, Rock \\
\hline 4 & Ain Sukhna II & 29.3100 & 32.2309 & Sand, Rocks, Seagrass \\
\hline 5 & Marine Station & 27.2835 & 33.7725 & Live coral, Sand, Rock \\
\hline 6 & Abu Monkar Island (West) & 27.2115 & 33.8786 & Rock, Live and dead corals, Sand \\
\hline 7 & El Gaftoon El-Sagher Island & 27.1861 & 33.9825 & Dead coral, Sand, Rock, Gravel \\
\hline 8 & Abu Ramad Island west & 27.1672 & 33.9805 & Live coral, Rock, Sand \\
\hline 9 & Abu Ramad Island South & 27.1575 & 33.9788 & Live coral, Rock, Gravel \\
\hline 10 & Gota Abu Ramad I & 27.1391 & 33.9532 & Live and dead corals \\
\hline 11 & Dishshet El-Dabaah & 27.0333 & 33.8842 & Sand, Seagrass, Coral rubble \\
\hline 12 & Sharm El-Arab & 26.9013 & 33.9631 & Live coral, Gravel, Seagrass \\
\hline 13 & Wadi Gwases & 26.5576 & 33.8733 & Dead coral, Sand, Seagrass \\
\hline 14 & Kalawy Beach & 26.3973 & 34.1213 & Live coral, Sand, Rock, Gravel \\
\hline 15 & Wadi Abu Hamrah & 26.2783 & 34.1833 & Sand, Dead coral, Gravel \\
\hline 16 & Mangrove village & 25.8710 & 34.4160 & Rock, Sand, Dead coral \\
\hline 17 & Sharm El-Bahari & 25.8702 & 34.4168 & Live coral, Sand, seagrass \\
\hline 18 & Marsa Trumbi & 25.6552 & 34.6045 & Dead coral, Rock \\
\hline 19 & Marsa Abu Dabab & 25.3415 & 34.7371 & Live and dead corals, Sand, Seagrass \\
\hline 20 & Marsa Abu Arikae & 25.2179 & 34.8032 & Dead coral, Rock, Sand, \\
\hline 21 & Marsa Gabal El-Rassas & 25.2048 & 34.8086 & Live coral, Rock, Sand \\
\hline 22 & Marsa Asslayah & 25.1561 & 34.8519 & Live and dead corals, Rock, Gravel \\
\hline 23 & Marsa Samadi & 25.0105 & 34.9230 & Dead coral, Sand, Seagrass \\
\hline 24 & Marsa El-Nakari & 24.9261 & 34.9230 & Dead coral, Rock, Sand \\
\hline 25 & Jibal El-Talayah & 24.7125 & 35.8388 & Live coral, Sand, Seagrass \\
\hline 26 & Wadi El-Jimal & 24.6583 & 35.0833 & Dead coral, Rock, Gravel, Sand \\
\hline 27 & Sharm El- Lolyah & 24.6068 & 35.1125 & Live coral, Rock, Gravel, Sand \\
\hline 28 & Ras Hankurab & 24.5725 & 35.0388 & Live coral, Sand, Seagrass \\
\hline 29 & Marsa Hamata & 24.2850 & 35.3773 & Rock, Gravel, Sand, Coral rubble \\
\hline 30 & (3 km) South Lahmmi & 24.1977 & 35.4205 & Dead coral, Rock, Sand, Seagrass \\
\hline 31 & Roman Village & 24.1727 & 35.4438 & Sand, Dead coral, Gravel, Seagrass \\
\hline 32 & Mowelhah fishing village & 24.0027 & 35.6805 & Sand, Rock, Dead coral \\
\hline 33 & Ras Benas & 23.9000 & 35.7833 & Sand, Rock, Live coral, Gravel \\
\hline 34 & El-Homirah & 23.4715 & 35.4869 & Dead coral, Sand, Seagrass \\
\hline
\end{tabular}


with the $70 \%$ ethanol, as the final fixative $[12,13]$.

\subsection{Morphological Examination, Identification and Measurement}

Specimens were examined, noting important diagnostic features [14]. The body of crinoids is supported by calcium carbonate skeleton covered by a tissue layer (=skin). The central body (=theca) that houses the viscera is composed of a series of articulated ossicles forming the calyx. The theca and pinnule-bearing arms (brachials) of stalked juvenile feather stars make up the crown, while unstalked adult feather stars have cirri characterized as long hook-like structures for attachment. The calyx is composed of five basal ossicles (=basals) which may be absent or reduced, and five radial ossicles (radials) that support the central disk. Ambulacral grooves extend from the mouth to the arms and pinnules. The centrodorsal (discoidal, hemispherical, cylindrical, star- or cone-shaped) is a large ossicle at the center of the aboral side of the body, where there are sockets for cirri attachment. Two arms, cirri, and the diameter of the central disk were measured in $\mathrm{cm}$. The status of each species was determined using the following categories.

- “Rare species” was applied when only 1 - 5 individuals of a species were present.

- “Common species” was given for a species having 5 10 individuals.

- “Abundant species" for a species has more than 10 individuals.

At the laboratory, crinoid specimens were sorted and identified using standard keys $[10,11,15,16]$. In addition, some important taxonomic works [17-21] were used in the identification of the specimen at the family, genus and species level.

The species list for the crinoids of the Red Sea and adjacent waters such as Arabian Gulf, Southeast Arabia and East Africa was compiled using the present data and information from the works of available literatures. The geographical distribution patterns of crinoid species, recorded in the present study and adjacent waters were compared.

The following terms are used in the identification and description of crinoid species (Figure 1).

Brachials: the calcareous ossicles of the arm (extending the division series).

Centrodorsal: the large plates occupying the center of the dorsal or aboral side, in shape discoidal, hemispherical, or sometimes conical and usually bearing cirri except on its apex or dorsal pole.

Cirri: the jointed appendages arising from the centrodorsal, for temporary attachment to the substrate.

Radials: the five plates from which the division series (or arms) arise; superficially they are only narrowly visi-

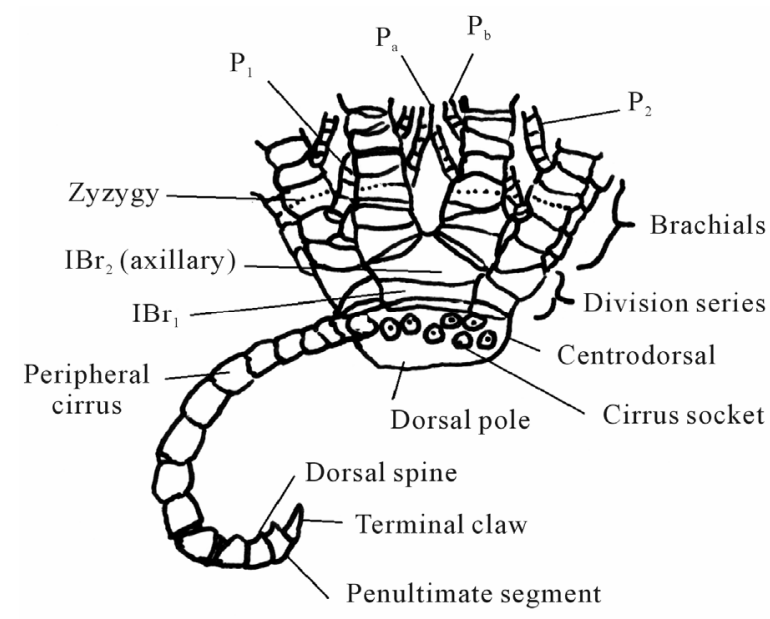

Figure 1. Introductory figure of crinoid, omitting to the arms, showing parts mentioned in terms (after Clark and Rowe, 1971).

ble in adults of most species.

Division series: the ossicles between the radials and the first brachials of the undivided arms absent only in five armed genera; the distalmost ossicle of the division series is an axillary.

Pinnules: the slender jointed appendages arising from the brachials on alternate sides, the proximal one or more of which are modified as oral pinnules. The pinnules on the outer (inter-radial) side of the arm are designated $\mathbf{P}_{\mathbf{1}}$, $\mathbf{P}_{2}$, etc. and the inner side $\mathbf{P}_{\mathbf{a}}, \mathbf{P}_{\mathbf{b}}$, etc.

Zyzygy: a rigid breaking-joint occurring at intervals in division series and arms, often regularly placed; the articulation is by ligament rather than muscles and the joint faces bear numerous fine radiating ridges so that externally the suture may appear discontinuous or undulating.

\section{Results}

\section{Key to the Species, Genera and Families Recorded in the Present Study}

1 Proximal pinnules very flexible and with some of the terminal segments modified to form a comb "Figure 2(a)"; mouth near the edge of the disc and anal tube approximately central.

COMASTERIDAE

- $\quad$ No comb on the proximal pinnules, their terminal segments simply tapering or only very finely thorny.

2(1) Only 10 arms; up to 13 cirrus segments at arm length 30 - $40 \mathrm{~mm}$.

Comissia hartmeyeri A. H.Clark, 1912. More than 10 arms; 14 or 15 cirrus segments at arm length 35 - 40 mm.

Capillaster multiradiatus (Linnaeus, 1758).

3(1) Middle and distal cirrus segments with a pair of 
dorsal spines or tubercles, one each side of the midline, rarely transverse ridge "Figure 2(b)".

\section{COLOBOMETRIDAE.}

Distal cirrus segments with a median prominence (dorsal spine, tubercle or longitudinal crest) or quite smooth "Figures 2(c) and (d)".

7

4(3) Cirri large with 36 - 48 segments, which have distinctly spinose distal edge.

Colobometra arabica A. H. Clark, 1937. Cirri smaller with $<30$ segments, their distal ends smooth.

5(4) Cirri wide and flat on the dorsal side, with curved transverse ridges or only small blunt paired tubercles; $\mathrm{P}_{2}$ stout and markedly prismatic with a saw-like profile (Figure 2(e)); $\mathrm{P}_{\mathrm{a}}$ (the pinnule in the inner side of the fourth brachial) present on all or most of the arm.

Oligometra serripinna (P. H. Carpenter, 1881). Cirri laterally compressed, not markedly flattened dorsally, the paired tubercles usually conical; $\mathbf{P}_{2}$ not conspicuously modified "Figure 2(f)"; $\mathbf{P}_{\mathrm{a}}$ absent often more than not.

\section{DECAMETRA.}

6(5) $\mathbf{P}_{2}$ over three times the length of $\mathbf{P}_{1}$; cirri numbering XVII-XXII, usually c. XX.

Decametra mollis (A. H. Clark, 1909). $\mathbf{P}_{2}$ rarely more than twice the length of $\mathbf{P}_{\mathbf{1}}$; cirri numbering XIII-XIX, usually c. XVI.

Decametra chadwicki (A. H. Clark, 1911).

7(3) The proximal pinnules at least with a slight, sometimes well marked, keel or series of processes on the dorsal side basally "Figure 2(g)", or else all the pinnules prismatic for their entire length; often more than 10 arms; the second brachial zyzygy usually farther out than brachials 9 and 10; the brachials distinctly wider than long for at least the proximal half of the arm, sometimes discoidal in shape.

No keel on the dorsal surface of any of the pinnules; only 10 arms; the second brachial zyzygy almost invariably at $9+10$; brachials after about the fourteenth usually as long as wide or longer and distinctly wedge-shape.

\section{ANTEDONIDAE}

8(7) Only the proximal pinnules at all prismatic; the distal pinnules, if not all of them, flexible and not conspicuously stiffened.

All the pinnules prismatic and conspicuously straight and stiff; 10 arms only and carinate dorsally, at least in the proximal half; no dorsal or ventral processes on the cirrus segments "Figure 2(d)".

(TROPIOMETRIDAE)

Tropiometra carinata (Lamarck, 1816).
9(8) Ten or more arms; if more than 10 then the external IIBr series at least usually of four ossicles "Figure 2(k)".

HIMEROMETRIDAE. 10

Always more than 10 arms, the IIBr series and any other division series of 2 ossicles "Figure 2(j)".

MARIAMETRIDAE.

11

10(9) Dorsal spines on the distal cirrus segments sharp and usually long, some cirrus segments longer than broad; usually 20 arms; $\mathbf{P}_{\mathbf{2}}$ and $\mathbf{P}_{\mathbf{3}}$ similar in size "Figure 2(f)".

Heterometra savignii (Muller, 1841). Spines or tubercles developed gradually over several cirrus segments, usually all short and blunt, cirri segments broader than long; 14 arms; $\mathbf{P}_{2}$ smaller than $\mathbf{P}_{3}$.

Heterometra atra (A. H. Clark, 1911).

11(9) One or more of the enlarged proximal pinnules $\left(\mathbf{P}_{2}\right.$, sometimes $\left.\mathbf{P}_{3}\right)$ very stiff and spike-like, often recurved over the disc; division series well separated with rounded ventrolateral extensions "Figure 2(h)".

STEPHANOMETRA.

12

Enlarged proximal pinnules (P2) tapering, slender and usually flexible; division series without ventrolateral extension, variable in form but the adjacent ones often straight-sided and closely approximating laterally "Figure 2(i)".

Lamprometra klunzingeri (Hartlaub, 1890).

12(11) $P_{3}$ and the following pinnules smaller and more flexible than $\mathbf{P}_{2}$ which is the only spike-like pinnule.

Stephanometra indica (Smith, 1876). $\mathbf{P}_{3}$ spike-like, resembling $\mathbf{P}_{\mathbf{2}}$ but usually smaller.

Stephanometra spicata (P. H. Carpenter, 1881).

13(7) $P_{3}$ the largest pinnule; cirrus segments overlapping the succeeding segments.

DOROMETRA.

$\mathbf{P}_{1}$ with only 8 - 11 segments and larger than $\mathbf{P}_{3}$.

Antedon parviflora (A. H. Clark, 1912).

14(13) Cirri relatively small, their length usually between a fifth and sixth of the arm length.

Dorometra parvicirra (P. H. Carpenter, 1888). Cirri larger, about a third of the arm length.

Dorometra aegyptica (A. H. Clark, 1911).

\section{Discussion}

Crinoids are prominent part of coral reef crypto fauna [22]. Although they are not as species rich (15 species) as ophiuroids 49 species [23], asteroids 36 species [24], holothuroids 28 species [25] or brachyuran crabs 361 species [26] and bivalves 180 species [27] many of such 


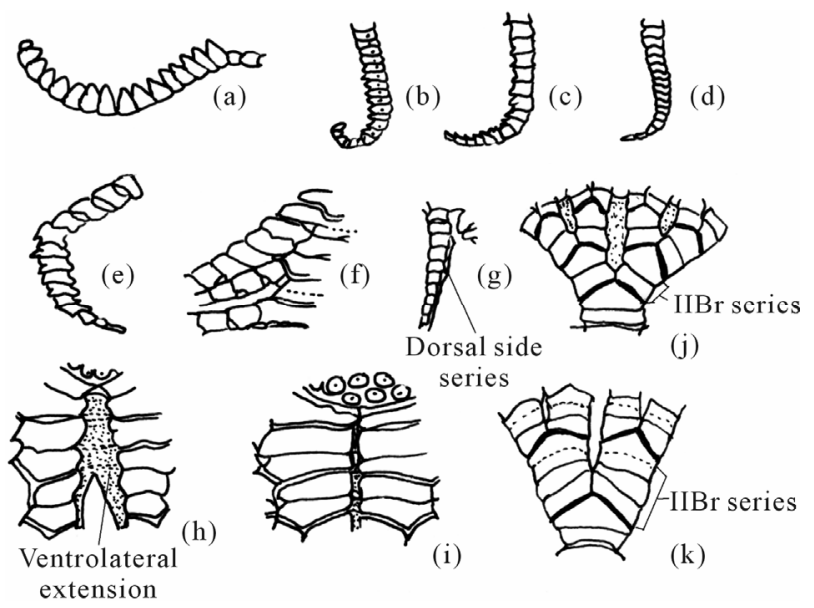

Figure 2. (a) Terminal comb of an oral pinnule of comasterids feather star; cirri of: (b) Colobometrid, genus $\mathrm{De}$ cametra (dorsal view); (c) Heterometra savignyii; (d) Tropiometra carinata (all side view); proximal pinnules: (e) $P_{2}$ of Oli-gometra serripinna; (f) Base of $P_{d}$ (pinnule of IIBr division series), P1 and P2 of Heterometra savignyii; (g) P2 of Tropiometra carinata (all right side of postradial series); interradii of: (h) Stephanometra indica; (i) Lamprometra klunzingeri; division series and arm base of a single radius of: (j) Mariametridae; (k) Himerometridae.

species are large in size and others are numerically abundant.

The total number of crinoids recorded in the Northern Red Sea and the areas used for comparison (adjacent waters as in $[10,18,20])$ were given in "Table 2". Also shown are the species that appear to be endemic. The total number of crinoid fauna recorded from the Red Sea in the present study is 15 species, belonging to 11 genera and 6 families. Gulf of Aqaba and Northern Red sea were the more diverse in their crinoid fauna than other areas, where they included 12 and 11 species respectively. While Gulf of Suez contained 9 species and Suez Canal comprised only two crinoid species. Most crinoids were recorded in Sothern Red Sea (12 species), with fewer and/or even less species in the East Africa, South-East Arabia and Arabian Gulf (5, 4 and 3 species respectively) as mentioned by some worker [10,18,20] (Table 2). All recoded crinoid species from the Red Sea are Indo-Pacific origin $[20,28]$. The Red Sea which considered one part of the Indo-Pacific region [10] is richer in its crinoid fauna (15 species, represented $10.9 \%$ of the total IndoPacific species) than the adjacent waters. For example, South East Arabia included 6 species (4.3\%) $[10,20]$. Also, references $[10,20]$ recorded 14 species $(10.1 \%)$ from East Africa and Madagascar and 6 species (4.3\%) from Arabian Gulf. Most of the recorded species in the above mentioned areas were found in the Red Sea. In contrast, the Red Sea considered very poor in its crinoid fauna if compared with other regions of the Indo-Pacific area. Reference [10] mentioned that Ceylon included 26 species (18.8\%) and North Australia contained 42 species $(30.4 \%)$. Of which only four species were found in the Red Sea. Whereas crinoid fauna at New Caledonia represented by 28 species (20.3\%) [16]. Such pattern of distribution and diversity did not agreed with general opinion as in $[20,28,29]$ that the Red Sea crinoid fauna is impoverished comparing with the fauna of adjacent waters and vise versa with other far waters of Indo-Pacific regions.

The degree of endemism in the Red Sea biota is difficult to evaluate, largely through insufficiency of taxonomic data and possible bias of certain taxonomists involved [20]. The proportion of endemic crinoids appears high (26.6\%) if compared with other groups of echinoderms. However, in major groups of animals within the Red Sea as a whole, the proportion of species that are endemic ranges from $10 \%-20 \%$ [20]; within smaller groups the proportion may even reach 50\% [29]. The tendency to produce endemic species appears to be great in areas like the Red Sea, which are almost completely enclosed and have environmental conditions differing from those of the neighbouring open sea.

Richness in species and high population are two of the most striking characteristics of the shallow water crinoid fauna along the coral reef of the northern Red Sea. This seems to contradict the assumption as in [15] that the comatulid fauna of coral reefs represents the "upper fringe" of a more extensive fauna in deeper waters. Of the northern Red Sea crinoids, 15 species are highly stenobathic; they inhabit waters above the $25 \mathrm{~m}$ isobaths, and only one species, Heterometra savignii, was collected at depths exceeding $30 \mathrm{~m}$. In contrast, in other parts of the Indo-Pacific basin, most of the comatulids are collected in fairly deep water [20]. Perhaps the benthic fauna of the Gulf of Aqaba exhibits a tendency to "shallowness". Possibly, the high degree of environmental complexity observed in shallow waters of the northern Red Sea is responsible for the pronounced diversification of the crinoid fauna. Along the coral reefs, between 1 to $25 \mathrm{~m}, 15$ crinoid species are found. Reference [30] mentioned that no benthic community has been defined yet in terms of its crinoid component. It seems that in future definitions of bathymetric zones in the northern Red Sea, the comatulids should be considered as an important element. These animals participate in the increase of species diversity, as well as in the consumption of large amounts of planktonic food. In the latter respect, they can compete with the reef coral population, on and among which they live and feed.

Shallow-water comatulids exhibit a circadian activity rhythm which declines with increasing depth and disappears at a depth of 15 to $20 \mathrm{~m}$ [31]. Some of the crinoids found in the northern part of the Red Sea are known only from this basin (Comissia hartmeyeri, Decametra chad- 
Table 2. List, distribution and status of crinoid species recorded from the Red Sea (present work) and adjacent areas.

\begin{tabular}{|c|c|c|c|c|c|c|c|c|c|}
\hline \multirow{3}{*}{ Families/Species } & \multicolumn{8}{|c|}{ Areas of study } & \multirow{3}{*}{ status } \\
\hline & \multicolumn{4}{|c|}{ Present work } & \multicolumn{4}{|c|}{ Adjacent areas (other works) $[10,18,20]$} & \\
\hline & Suez Canal & $\begin{array}{l}\text { Gulf of } \\
\text { Suez }\end{array}$ & $\begin{array}{l}\text { Gulf of } \\
\text { Aqaba }\end{array}$ & $\begin{array}{l}\text { North Red } \\
\text { Sea }\end{array}$ & $\begin{array}{c}\text { South Red } \\
\text { Sea }\end{array}$ & $\begin{array}{l}\text { Arabian } \\
\text { Gulf }\end{array}$ & $\begin{array}{c}\text { South-east } \\
\text { Arabia }\end{array}$ & East Africa & \\
\hline \multicolumn{10}{|l|}{ Family: Comasteridae } \\
\hline Comissia hartmeyeri* $^{*}$ & & + & + & & & & & & $\mathrm{C}$ \\
\hline Capillaster multiradiatus & & & + & + & + & & & + & $\mathrm{C}$ \\
\hline \multicolumn{10}{|l|}{ Family: Colobometridae } \\
\hline Colobometra arabica & & & + & + & + & & & & $\mathrm{R}$ \\
\hline Oligometra serripinna & & $+\dagger$ & + & + & + & & + & + & A \\
\hline Decametra mollis & & + & $+\dagger$ & $+\dagger$ & + & + & & & $\mathrm{R}$ \\
\hline Decametra chadwicki* & $+\dagger$ & + & + & & & & & & $\mathrm{C}$ \\
\hline \multicolumn{10}{|l|}{ Family: Tropiometridae } \\
\hline Tropiometra carinata & & + & + & + & + & & + & + & A \\
\hline \multicolumn{10}{|l|}{ Family: Himerometridae } \\
\hline Heterometra savignii & & + & + & + & + & + & + & & $\mathrm{C}$ \\
\hline Heterometra atra* & & & + & + & + & & & & $\mathrm{R}$ \\
\hline \multicolumn{10}{|l|}{ Family: Mariametridae } \\
\hline Lamprometra klunzingeri & $+\dagger$ & + & + & + & + & + & + & + & A \\
\hline Stephanometra indica & & + & & + & + & & & + & A \\
\hline Stephanometra spicata & & & & + & + & & & & $\mathrm{R}$ \\
\hline \multicolumn{10}{|l|}{ Family: Antedonidae } \\
\hline Antedon parviflora & & & + & & & & & & $\mathrm{R}$ \\
\hline Dorometra parvicirra & & & & + & & & & & $\mathrm{R}$ \\
\hline Dorometra aegyptica* & & $+\dagger$ & $+\dagger$ & & & & & & $\mathrm{C}$ \\
\hline Total number of species & 2 & 9 & 12 & 11 & 10 & 3 & 4 & 5 & \\
\hline
\end{tabular}

${ }^{*}=$ Endemic species to the Red Sea; $\dagger=$ New record; $A=$ Abundant; $C=$ Common; $\mathrm{R}=$ Rare.

wicki); others are distributed far out into the S. W. Pacific Ocean (Eudiocrinus serripinna, Oligometra serripinna), or to the W. Indies (Tropiometra carinata). However, there is no barrier to the identity of Red Sea and Pacific species [10].

\section{Conclusion}

This study revealed that 15 crinoid species are known from the Red Sea belonging to 11 genera under 6 families. Among them 4 species are endemic to the Red Sea, two species from Suez Canal and other two species from Gulf of Suez, in addition, one species from Gulf of Aqaba and Northern Red Sea are recorded for the first time.

\section{Acknowledgements}

The author would like to thank the EEAA, Egypt and Manager of GEF Project (Egypt, 1996-1998) for the facilities and travelling to the Red Sea areas during the sampling collection used in present study.

\section{REFERENCES}

[1] L. H. Hyman, “The Invertebrates. IV. Echinodermata,” McGraw Hill, New York, 1955.

[2] B. Grzimek, "Lower Metozoans and Lesser Deuterostomes," Animal Life Encyclopedia: Mollusks and Echinoderms, 2nd Edition, Vol. 1, Van Nostrand Reinhold Company, New York, 2003. 
[3] W. I. Ausich and C. G. Messing, "Crinoidea. Sea Lilies and Feather Stars," Version 21, The Tree of Life Web Project, 1998. http://tolweb.org/

[4] D. I. Meyer and D. B. Macurda Jr., "Ecology and Distribution of the Shallow-Water Crinoids (Echinodermata) of the Palau Islands and Guam (Western Pacific),” Micronesica, Vol. 16, 1980, pp. 59-99.

[5] C. G. Messing, "A Revision of the Recent Indo-West Pacific Comatulid Genus Comaster Agassiz. Part 1: The Type Species of Comaster and Phanogenia Lovén (Echinodermata: Crinoidea: Comasteridae)," Invertebrate Taxonomy, Vol, 12, No. 2, 1998, pp. 191-209. doi:10.1071/IT97004

[6] C. G. Messing, "Three New Species of Comasteridae (Echinodermata: Crinoidea) from the Tropical Western Pacific,” Zoosystm, Vol. 25, No. 1, 2003, pp. 149-162.

[7] L. Kirkendale and C. G. Messing, "An Annotated Checklist and Key to the Crinoidea Guam and the Commonwealth of the Northern Mariana Islands,” Micronesica, Vol. 35-36, 2003, pp. 523-546.

[8] K. B. Tomasz, “Crinoid Ecological Morphology,” Annual Review of Earth and Planetary Sciences, Vol. 36, No. 7, 2008, pp. 221-249. doi:10.1146/annurev.earth.36.031207.124116

[9] C. Carmen, R. M. Arguelles, D. Paz1 and G. C. Florencia, "Identification of Feather Stars (Echinodermata: Crinoidea: Comatulida) at Subic Bay, Zambales, Philippines,” Philippine Journal of Science, Vol. 139, No. 1, 2010, pp. 51-60.

[10] A. M. Clark and F. E. W. Rowe, "Monograph of Shallow Water Indo-West Pacific Echinoderms," Trustees of the British Museum (Natural History), London, 1971.

[11] A. R. G. Price, "Echinoderms of Saudai Arabia. Echinoderms of the Arabian Gulf Coast of Saudi Arabia," Fauna of Saudi Arabia, Vol. 5, 1983, pp. 28-108.

[12] G. Hendler, "Collecting, Preserving and Archiving Echinoderms,” Natural History of Los Angeles, County, Los Angeles, 2004.

http://clade.ansp.org/malacology/people/rosenberg/archivi ng/taxa/echinoderms.html

[13] C. G. Messing, "Charles Messing's Crinoid Pages Florida: Nova Southeastern University Oceanographic Center," 2006. http://www.nova.edu/ocean/ messing/crinoids/

[14] G. Rouse, C. G. Messing and L. Johnston, "Crinoidea: Featherstars and Sea Lilies Australia: Australian Biological Resources Study,” 2006.

http://geolog008.geology.adeliade.edu.au/CrinoideaSite/ webcontent/pages/welcome.html

[15] H. L. Clark, "A Monograph of the Existing Crinoids. Volume 1. The Comatulids. Part 2," Bulletin of the United States National Museum, Vol. 82, 1921, pp. 1-57.

[16] A. Guille, A. Laboute and J. L. Moneu, “Guide des Etoiles de Mer Oursins et Outers Echinodermes du Lagoon de Novelle Caledonie,” ORSTONO, 1986, p. 283.
[17] A. H. Clark, "A Monograph of the Existing Crinoids. I (3): Superfamily Comasterida,” Bulletin of the American National Museum, Vol. 82, 1931, pp. 31-816.

[18] D. B. James and J. S. Pearse, "Echinoderms from the Gulf of Suez and Northern Red Sea," Journal of the Marine Biological Association of India, Vol. 1, No. 1-2, 1969, pp. 78-125.

[19] A. R. G. Price, "Studies on the Echinoderm Fauna of the Western Arabian Gulf,” Journal of Natural History, Vol. 15, No. 1, 1981, pp. 1-15. doi:10.1080/00222938100770011

[20] A. R. G. Price, "Echinoderms of Saudi Arabia. Comparison between Echinoderm Faunas of Arabian Gulf, SE-Arabia, Red Sea and Gulfs of Aqaba and Suez," Fauna of Saudi Arabia, Vol. 4, 1982, pp. 3-21.

[21] F. E. W. Rowe, A. K. Hoggett, R. A. Birtles and L. L. Vail, "Revision of Some Comasterid Genera from Australia (Echinodermata: Crinoidea), with Descriptions of the Two New Genera and Nine New Species,” Zoological Journal of the Linnean Society, Vol. 86, 1986, pp. 197277. doi:10.1111/j.1096-3642.1986.tb01812.x

[22] N. A. Sloan, "Size and Structure of Echinoderm Populations Associated with Different Coexisting Coral Species at Aldabra Atoll,” Marine Biology, Vol. 66, 1982, pp. 67-75.

[23] A. M. Hellal, "Taxonomy and Zoogeography of the Red Sea Ophiuuoidea (Brittlestars),” Ph.D. Thesis, Al-Azhar University, Cairo, 1990.

[24] M. M. Fauda and A. M. Hellal, "Fauna and Flora of Egypt. The Echinoderms of the Northwestern Red Sea. Asteroidea,” Natural History Museum of Egypt, Cairo, 1987, pp. 1-71.

[25] A. M. Hellal, "Contribution to the Sea Cucumber Fauna (Echinodermata: Holothuroidea) at the Vicinity of Bab El-Mandab, Red Sea Yemen,” Al-Azhar Bulletin of Science, Vol. 21, No. 1, 2010, pp. 27-65.

[26] P. Vine, “Red Sea Invertebrates,” Immel Publishing, London, 1986, pp. 1-224.

[27] D. Sharabati, "Red Sea Shells," Chapman and Hall, Routledge, 1985, pp. 1-128.

[28] A. C. Campbell, "Echinoderms of the Red Sea,” In: A. J. Edwards and S. M. Head, Eds., Key Environments Red Sea, Pergamon Press, Oxford, 1987, pp. 215-232.

[29] G. Bermet and R. Ormond, "Red Sea Coral Reefs," Keegan Paul International Ltd., London, 1981.

[30] H. B. Fell, “The Echinodermata,” In: T. J Parker and W. A Haswell, Eds., Text Book of Zoology, 7th Edition, Vol. 1, Macmillan, London, 1966.

[31] J. L. Rutman and L. Fishelson, "Comparison of Reproduction in the Red Sea Feather-Stars Lamprometra klunzingeri (Hartlaub), Heterometra savignii (J. Muller) and Capillaster multiradiatus (L.),” Echinoderms, 19841985, pp. 195-220. 